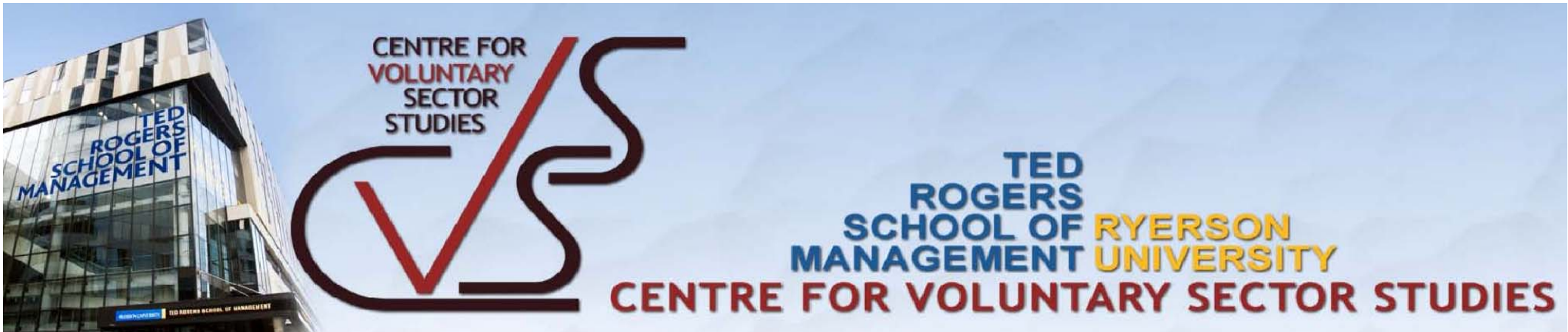

\title{
A Portrait of School Community Service Programs in Canada
}

\author{
Agnes Meinhard \\ Centre for Voluntary Sector Studies, Ryerson University \\ Steven Brown \\ Laurier Institute for the Study of Public Opinion and Policy, \\ Wilfrid Laurier University
}

Working paper series

Volume 2007 (1)

350 Victoria Street

Toronto, Ontario M5B 2K3

Tel: 416-979-5146 x 6739 / Fax: 416-979-5124

cvss@ryerson.ca

http://www.ryerson.ca/cvss/working_papers 


\section{Abstract $^{1}$}

Although community service programs are to be found across the Canadian landscape, there have been no national initiatives to standardize programs. Thus, the place and nature of community service in high school curricula vary significantly among the 13 educational jurisdictions in Canada. The greatest differences however, are to be found among individual schools within each jurisdiction. This paper presents findings from interviews with keyinformants to provide a more in-depth portrait of the programs in Canadian schools. Community service practices in Canadian schools are then discussed in the context of "best practices" as described in the literature.

\section{Introduction}

Promoting civic development in young people through school-based community service programs has become a key educational goal in many countries (Arenas, Bosworth \& Kwandayi, 2006). Documentation describing a wide variety of programs is now available in various bodies of literature: academic, educational and practitioner. In educational jurisdictions the world over, governments are actively promoting the inclusion of community service programs in the curriculum, often as a mandatory component towards graduation. This new interest by governments to promote community service in educational institutions is based, in part, on the belief that volunteering to serve one's community creates strong communal values and better citizens. It also encourages collaborative behaviour, a form of social capital that is necessary to compete in a knowledge-based global economy (Putnam, 1995).

In the United States, as of 2004, 83\% of public high schools were offering community service programs ${ }^{2}$ of one kind or another and $44 \%$ of all schools were mounting service learning programs $^{3}$ (Scales \& Roehlkepartain, 2004). As Arenas, Bosworth, and Kwandayi (2006) demonstrate, this is truly a global trend. Similar initiatives are to be found in all developed countries, and school-related civic engagement programs are also found in developing countries such as Botswana, Nigeria, Colombia, Trinidad and Tobago, China, Tanzania, Mozambique, and Cuba.

In Canada, community service programs are not as prevalent as in the US (Brown, Meinhard, Ellis-Hale, Henderson, \& Foster, 2006). There have been no country wide initiatives such as the "Learn and Serve America" program nor have there been the kind of nation-wide calls for the inclusion of community service programs in schools as issued in the U.S. by Goodlad (1984) and Boyer (1983) and the Carnegie Task force on Education of Young

\footnotetext{
${ }^{1}$ This study was supported, in part, by a grant from the Knowledge Development Centre as part of the Canada Volunteerism Initiative, Department of Canadian Heritage.

${ }^{2}$ Community Service Program is a program in which students, without pay, perform service designed to benefit the community; the program is non-curriculum-based, may be mandatory or voluntary, does not usually include explicit learning objectives or organized reflection, and may include activities that take place on or off the school grounds.

${ }^{3}$ Service Learning Program is a community service program in which the service is integrated into an academic course or curriculum; as such, the service has clearly stated learning objectives, and there is an opportunity as part of the course for students to engage in reflective or critical analysis about their service experience.
} 
Adolescents (1989). Although one can only speculate as to why this is so, it may have its basis in a fundamental difference between the two countries. In the US, where service learning has been approached with renewed vigour over the past 3 decades, it is seen as an antidote to the steady decline in communal and civic participation. It seems that in the constant American struggle to balance individualism and community, individualism is prevailing (Barber, 1992; Bellah, Madsen, Sullivan, Swindler \& Tipton, 1985; Putnam, 1995). This tension between individual pursuit of happiness and the good of the community that many scholars have remarked upon in the United States (Barber, 1992; Bellah et al., 1985, Putnam, 1995) is not a characteristic feature of Canada. As opposed to every individual's right to "Life, Liberty and the Pursuit of Happiness," as stated in the Declaration of Independence, the preamble of Canada's Constitution Act of 1867, talks of "Peace, Order and Good Government". In the struggle to keep the wide territorial expanse that is Canada together, the common good generally took precedence over individual rights and the Canadian government has always been an active participant in the welfare of its citizens. Thus the partnership between the voluntary sector and the government took a different form in Canada from that in the U.S. (Evans \& Shields, 1998). The deep-seated belief in a strong state role in society has only recently been undermined under the influence of “the new competitive global order” (Evans \& Shields, 1998:17). This has been accompanied by calls for instilling community values in Canadian youth by requiring them to perform community services.

Interest in community service is a new phenomenon in Canada, both from a policy perspective and a research perspective. Because of a lack of research, not much is known historically about the prevalence of such programs. However, based on a survey of secondary schools in the Greater Toronto Area (Meinhard \& Foster, 1998), it is safe to infer that community service programs have been part of the curriculum in a number of Canadian schools for several years. The programs were offered at the discretion of the individual schools, often the result of the efforts of a single teacher in a single class. There were no centralized programs either at the level of school boards, or at the level of provincial ministries of education.

This paper presents findings from the first national survey of community service programs in Canada.

\section{Study Description}

In 2006 a team of researchers from Ryerson University and Wilfrid Laurier University conducted a nationwide survey to determine the pattern and salient features of high school community service programming in each of Canada's ten provinces and three territories. Ninety percent of Canada's 372 school boards were contacted. In most cases school board officials referred the interviewers to principals, guidance counselors or teachers knowledgeable about community service programs in their jurisdictions. Through this process, interviews were secured with a total of 254 principals, guidance counselors, or individual teachers. An additional 66 interviews were conducted with representatives from private schools for a total of 320 interviews. 
Survey questionnaires that indicated interesting, comprehensive and exemplary community service programs were flagged. In these cases the original respondents were recontacted and asked to participate in a longer, more detailed interview concerning their programs. Because there were only a few comprehensive and distinctive program models in Canada, our final sample of school informants for these in-depth explorations is drawn from three schools and two school boards, one public and one religious.

With few exceptions (notably Sundeen \& Raskoff, 1994), studies investigating community service programs focus mainly on the schools, rather than on the community organizations. Since relations with voluntary sector organizations are an important component of program structure, we decided to include the perspective of community organizations as well. Volunteer coordinators or development officers from five nonprofit agencies were interviewed.

The interviews were guided by protocols established from information gleaned in the literature review. For school representatives, thirty-three questions were organized into five sections probing different aspects of the community service program: a) program details; b) teacher/staff involvement; c) school-community liaison; d) perceived student experiences; and e) advice for best practices. For key-informants from voluntary organizations, twenty-one questions were organized into four sections probing different aspects of the community service program:

a) context; b) arrangements with schools or school boards; c) nature of school involvement; d) overall impressions.

All interviews were conducted over the phone and recorded with the permission of the interviewees. The recordings were transcribed and then content analyzed. The entire interview process adhered to the Tripartite Ethical Guidelines and was approved by the Ethics Review Boards of both universities.

We present first, a summary of the findings of the initial survey. (The full report can be accessed at ImagineCanada.ca.pdf). Then, based on the in-depth interviews with key informants from schools, school boards, and voluntary agencies, we draw a more detailed portrait of the programs offered in Canada. Finally, we discuss these findings in the context of "best practices" as described in the literature.

\section{Brief Summary of Community Service in Canadian Schools}

The predominant conclusion of our study is that community service is not a prominent feature in Canada's secondary schools. Provincial guidelines, where they exist, are vague and it is generally left to the individual boards or schools to flesh out the program. This is true even in provinces where community service is a mandated requirement for graduation from high school.

Programming across the thirteen educational jurisdictions in the country varies significantly. Four jurisdictions have no provincially mandated community service programs, three jurisdictions strongly encourage schools to adopt community service by providing incentives and/or guidelines, four are planning to establish mandatory programs and two have them in place already. Number of required service hours and types of service eligible vary 
greatly; in some provinces community service is broadly defined to include internships at forprofit corporations.

These provincial and territorial differences notwithstanding program variations are greater between schools in the same jurisdictions, than between jurisdictions. Three factors help explain these school level differences:

- The most significant factor is whether the school is faith based or secular; Faith-based schools are more likely to promote community service.

- Private schools take a more active role in community service.

- Community service is a core component of schools that are members of the International Baccalaureate Organization.

\section{In-depth Portrait of Exemplary Programs}

The in-depth interviews focused around four main themes: program context, recruitment and placement, students’ volunteering experiences and suggestions for best practices

\section{Program context}

We learned from our interviewees that guidelines and protocols informing community service programs are brief, and mostly insubstantial. The boards give schools autonomy with respect to their community service programming, even where community service is mandated, as long as the minimum requirements are fulfilled. Few schools have anything more than informal guidelines. From time to time, some programs require insurance and/or parental consent. With respect to relationships with voluntary agencies, there are likewise few formal, written arrangements. Some programs involve group volunteering, where students go as a group to their placement with a teacher or staff member supervising, arrangements having been made ahead of time between the school and the voluntary organization. One large volunteer centre had exchanged some written documentation towards establishing a partnership with two school boards. Another agency referred to a "letter of understanding" that it sends to both schools and parents. But on the whole, written agreements are not common practice. Instead, there are verbal understandings between the schools and the agencies with respect to expectations. These understandings are based to a large degree on trust, as there is no indication of systematic followup or general program evaluation. One of the schools reevaluates an agency only in the event of student complaints or dissatisfaction. Similarly, two of the agencies said that they have contacts with the schools only in the event of problems with the volunteers. Teachers and staff involved in community service complained of lack of resources for the program, both human and financial. Few teachers are involved in community service and they are quite apathetic about the program. In summary, even among these exemplary schools and boards, community service programs are not formally structured. 


\section{Recruitment and placement}

In keeping with the lack of formality regarding program protocols and agency partnerships, the recruitment methods and placement procedures are generally not systematized. All the schools and boards interviewed have information about community service on their websites. Some have dedicated web pages for their community service programs, listing the details and requirements of the program as well listing some agencies students can approach; some augment this by distributing brochures and posting information on school bulletin boards and in school newsletters. Generally, students find placements on their own, without the help school officials. One school organizes a special assembly to provide information about the program. Another invites parents to these assemblies and yet another conducts volunteer fairs where local agencies display their organizational literature and explain to the students what they do. Two volunteer centres in our sample are proactive and reach out to schools in various ways; in one city the organization arranges a central volunteer fair. In the other there is an initiative to engage youth by forming relationships with two school boards. Direct service agencies make no attempts to be proactive, although they do welcome their high school volunteers and are comfortable with signing off on their hour-tracking sheets. On the whole, the agencies welcome the opportunity to host student volunteers, although some reported that students can be more of a bother than a help, and need more training and supervision than adult volunteers.

\section{Volunteering experience}

With only few exceptions, our respondents feel that students are given adequate levels of responsibility in their placements, with many agencies adapting to the needs of the student volunteer. Some agencies have an age threshold for volunteering, so only senior students are accepted. Some noted that students require more training and supervision than adult volunteers, while others treat the students in the same manner as adult volunteers. This notwithstanding, schools still receive complaints about volunteer placements that fail to provide an enriching experience.

In one exemplary program, a team of students is in charge of evaluating proposals submitted by students from area schools requesting funding for community service projects. This “for youth, by youth” program involves students at all levels of decision making and leadership activity, both at the agency level where granting decisions are made and at the school level, where students are actively involved in the preparation of the proposals and implementing the projects.

In the opinion of all our school respondents, without exception, the main goals of their programs are being met: students become more socially aware, they learn about responsibility and leadership, they are exposed to social justice issues and are involved not only in charitable actions but also in community building. There is general agreement among our respondents that community service volunteering teaches students what the classroom cannot. One respondent talked about the role community service plays in enhancing emotional intelligence. All of our 
respondents see community service programs in the schools as a positive initiative, especially when the duration of volunteering is extensive.

A caveat is in order here. Our respondents themselves were quick to point out that these observations are not based on systematic evaluations or surveys, but rather on anecdotal evidence from student comments or journal entries, or individual observations of changes in students.

\section{Best practices as recommended by interviewees}

The final question in our interview asked the respondents to reflect on what best practices they would recommend to schools and agencies when setting up a community service program. Meaningful volunteering which offers opportunities for leadership, decision-making, learning and expanding oneself and one's skills, was mentioned by virtually all the respondents. The need to integrate community service with classroom experience was frequently mentioned. Interestingly, individual reflection in the form of personal journals, sharing experiences with classmates and/or adult supervisors, was not mentioned, even though in the course of the interviews it was clear that two of the schools encouraged journal-keeping and information sharing. The importance of listening to students and what they have to say about their experiences was emphasized by all school respondents.

A disagreement was noted among our respondents with respect to the mandatory nature of the high school community service initiative. Two school respondents thought that it is best to keep community service programs voluntary, while extending some form of recognition as added incentive, for example: volunteer appreciation events, medals, certificates, bonus points, or extracredits. One respondent however, was firm in his opinion that making the program mandatory helps engage all students, especially those "at risk". This respondent also felt that making the program mandatory raises greater awareness and interest among teachers as well and would likely bring more community service perspective into the classroom.

Almost all of the school respondents spoke of the need to provide incentives to teachers to encourage greater involvement. Even in the private schools, teacher participation is relatively low. Two school respondents and one board respondent suggested having at least a half time position dedicated to coordinating community service programs, especially in cases where they are mandatory. There was also general agreement that increased financial support would be helpful in improving the programs. This was echoed at the agency level as well.

One suggestion for best practice was to encourage and teach students to conduct a brief "information interview" with potential placements. This would help them determine whether the placement matched their interests and aptitudes. "Good fit" is seen as important in ensuring a positive volunteering experience, which in turn is important in providing a foundation for future volunteering. Finally, several interviewees emphasized that volunteering should be fun!

Knowing the community and having a network of contacts is considered essential, especially in smaller communities One respondent suggested that community service "is a way to build capacity to understand the magnitude of community issues", therefore it is important to present and structure the community service program not as a charitable act, where the student is only giving to the needy, but rather as being part of a community mobilization effort to solve its 
own problems. Seeing that their work "makes a difference in the community is a very powerful experience” for students.

Parental involvement is another factor that our respondents consider important. "Getting the parents on side" and creating programs that mobilize families in community efforts were both suggested as helping increase student volunteering rates. Two agency respondents however, complained about parental interference when it came to ensuring that their children completed their mandatory hours, begging for placements, and even arguing about hours credited. One agency thought group volunteering can add to the students' experience, while acknowledging that sometimes in groups the students do not take the project seriously.

\section{Discussion}

The lack of structure in these Canadian programs is worrisome. The consensus in the literature is that well-designed programs are more likely to have both short- and long-term impacts on students (Billig, 2000; Eyler \& Giles, 1999; McLelland \& Youniss, 2003; Youniss, McLelland \& Mazer, 2001). The clearest results are found in the area of student satisfaction: carefully structured programs lead to greater student satisfaction (Meinhard, Foster \& Wright, 2006; Pancer, Brown, Henderson, \& Ellis-Hale, 2007). In our review of the literature we identified four design features related to success: two were student-focused - dealing with quality of student placements and internalizing the experience through reflection and relevance; and two focused on administrative features - covering program design and teacher support.

\section{Quality of student placements}

Of all the program design features, those relating to the quality of the student placements were the most frequently mentioned in the literature:

- Giving students responsibility (Billig, 2000 \& 2002; Conrad \& Hedin, 1991; Eyler \& Giles, 1999; Maybach, 1996; Meinhard, Foster \& Wright, 2006; Melaville Berg \& Blank., 2006; Shumer, 1994 \& 1997; Shumer \& Belbas, 1996; Sundeen \& Raskoff, 1994).

- Providing meaningful and/or challenging tasks (Billig, 2000; Billig \& Welch, 2004; Conrad \& Hedin, 1987; Eyler \& Giles, 1999; Meinhard, Foster \& Wright, 2006; Melaville Berg \& Blank., 2006; Sundeen \& Raskoff, 1994),

- Providing opportunities for leadership and decision-making (Billig, 2000; Flanagan, 2004; Meinhard, Foster \& Wright, 2006; Melaville, Berg \& Blank., 2006; Sanders, 2003; Stoneman, 2002; Sundeen \& Raskoff, 1994),

- Helping students choose placements (Billig, 2000; Conrad \& Hedin, 1987; Shumer, 1997)

- Matching them to their interests and abilities (Billig, 2002; Billig, 2000; Billig \& Welch, 2004; Clary \& Snyder, 1999; Conrad \& Hedin, 1987; Melchior, 1998). 
Our respondents confirmed the importance of student experiences in the descriptions of their programs and their suggestions for best practices. They felt that their programs offered the students leadership opportunities and gave them responsibility to make their own decisions. However, with respect placements, the description of their recruitment practices did not seem to indicate that strong attention was paid to matching placements to students' interests and abilities. The suggestion by one of our interviewees to have students conduct "information interviews" before deciding on a placement, would go far to ensure a proper match.

\section{Internalizing the volunteer experience}

In addition to providing the students with good volunteering experiences, the literature also places high importance on helping the students to process and internalize their experiences. The two main routed to this are:

- Reflecting on the volunteer experience, in terms of personal and community benefits (Billig,2000 \& 2002; Billig \& Welch, 2004; Conrad \& Hedin, 1987; Conrad \& Hedin, 1991; Eyler \& Giles, 1999; Melaville Berg \& Blank., 2006; Shumer, 1994 \& 1997; Shumer \& Belbas, 1996) and,

- Building on prior knowledge and linking community service to curriculum or courses (Billig, 2000 \& 2002; Melaville Berg \& Blank., 2006; Shumer, 1994 \& 1997; Shumer \& Belbas, 1996).

While our key informants did emphasize the importance of integrating the volunteering experience with classroom experience and listening to what the students had to say, they never spoke directly of providing opportunities for student reflection. This, despite the fact that they alluded to their students' diaries, thus indicating that reflection was an element of at least some of their programs. Linking community service to curriculum can really be considered another way of reflecting on the experience. 


\section{Program design}

It is perhaps in the program design aspects that the Canadian experience falls short of ideal. The literature emphasizes the importance of creating and maintaining structures that help to ensure the quality of the student experience such as:

- Having regular communication/ partnerships between schools and agencies (Billig, 2000 \& 2002; Conrad \& Hedin, 1991; Sanders, 2003; Shumer, 1994 \& 1997; Shumer \& Belbas, 1996; Sundeen \& Raskoff, 1994);

- Ensuring adult involvement in the student experience (Blythe, Saito, \& Berkas, 1997; Conrad \& Hedin 1987; Meinhard, Foster \& Wright, 2006; Melaville Berg \& Blank., 2006; Shumer, 1994 \& 1997; Stoneman, 2002).

- Increasing the duration and intensity of involvement (Billig, 2000 \& 2002; Blythe, Saito, \& Berkas, 1997; Shumer \& Belbas, 1996),

- Clearly delineating the educational goals of the program (Billig, 2002; Clary \& Snyder, 1999; Kahne \& Westheimer, 1996; Stoneman 2002)

- Engaging in systematic program evaluation (Billig, 2000 \& 2002; Conrad \& Hedin, 1987; Shumer \& Belbas, 1996)

While some of these items were suggested as best practices by our respondents, with the exception of ensuring adult involvement, none of these activities was practiced.

\section{Support for teachers and administrators of community service programs}

The literature is clear on the importance of providing adequate resources and support for these programs in the form of:

- Financial, administrative and collegial support (Billig \& Welch, 2004; Melaville, Berg \& Blank., 2006; Sanders, 2003; Stoneman, 2002); and

- Appropriate training for teachers and administrators of community service programs (Billig \& Welch, 2004; Melaville, Berg \& Blank., 2006; Shumer 1997; Shumer \& Belbas, 1996).

Our respondents were also very clear as to the lack of resources and support, and they were equally clear that this is an important feature and should be included in any discussion of best practices.

\section{Conclusion}

There is broad consensus in the literature about the key elements necessary for creating successful community service programs. Of uppermost concern is ensuring that the student experience is not only positive, but also character building - giving students responsibility and providing them with opportunities to apply new ideas, solve problems, make decisions and build leadership skills. In order for this to happen, certain program structural features, both pedagogical and administrative, need to be present. 
Giving students tools to understand how their service relates to the community, to society and to their own personal growth is an important pedagogical goal. This is best achieved by setting clear educational goals, providing students with opportunities for reflection and linking their community service experience to prior knowledge and course-work. Teacher participation is also important, both for helping students find appropriate placements and for being available to hear of their successes, help out when they have problems and provide them with feedback.

Program administration involves: establishing contacts and partnerships with community agencies; making sure they provide students with meaningful work and challenging tasks; engaging in systematic program evaluation (including the performance of partner agencies); and ensuring that program goals are being met and students are well-placed and fulfilling their requirements. Administratively a key component of good service programming is having sufficient financial and human resources available to run the program.

Both the nationwide survey of Canadian community service programs and the in-depth interviews with key informants representing some of Canada's more exemplary programs indicate that community service, as practiced in Canadian high schools is far from ideal. The success reported by some of the respondents is due more to the individual efforts of the program administrators than to formal program structure. If, as reported in some previous Canadian research (Meinhard, Foster \& Wright, 2006; Padanyi, Meinhard \& Foster, 2003; Pancer, Brown, Henderson \& Ellis-Hale, 2007), future civic engagement is contingent on the quality of the volunteering experience, then greater effort should be placed on providing the necessary elements of infrastructure, as described above, to ensure that this will be achieved.

\section{References}

Arenas, A., Bosworth, K., \& Kwandayi, H. P. (2006). Civic service through schools: An international perspective. Compare 36(1), 23-40.

Barber, B. (1992). An aristocracy of everyone. New York: Ballantine.

Bellah, R., Madsen, R., Sullivan, W., Swidler, A., \& Tipton, S. (1985). Habits of the heart. Berkeley: University of California Press.

Billig, S. (2000). Research on K-12 school-based service-learning: The evidence builds. [Electronic version]. Phi Delta Kappan, 81(9), 658-664.

Billig, S. (2002). Adoption, implementation, and sustainability of K-12 service-learning. In A. Furco, \& S. H. Billig (Eds.), Service-learning: The essence of the pedagogy (pp. 245267). Greenwich, Connecticut: Information Age Publishing.

Billig, S., \& Welch, M. (2004). Challenges and strategies in higher education and K-12 settings. In M. Welch, \& S. Billig (Eds.), New perspectives in service-learning: Research to advance the field (pp. 221-241). Greenwich, CT: Information Age Publishing. 
Blyth, D. A., Saito, R., \& Berkas, T. (1997). A quantitative study of the impact of servicelearning programs. In A. S. Waterman (Ed.), Service-learning: Applications from the research. (pp. 39-56). Lawrence Erlbaum Associates, Publishers, Mahwah, NJ: US.

Boyer, E. (1983). High School. New York: Harper and Row.

Brown, S. D., Meinhard, A., Ellis-Hale, K., Henderson, A. \& Foster, M. (2007).

Community Service and Service Learning in Canada: A Profile of Programming across the

Country. Toronto: Imagine Canada. ImagineCanada.ca.pdf

Carnegie Task Force on Education of young Adolescents. (1989). Turning Points: Preparing

American youth for the 21st century. New York: Carnegie Council on Adolescent

Development of the Carnegie Corporation.

Clary, E. G., \& Snyder, M. (1999). The motivations to volunteer: Theoretical and practical considerations. Current Directions in Psychological Science, 8, 156-159

Conrad, D., \& Hedin, D. (1987). In Atlantic Richfield Foundation, Los Angeles, CA., Ford Foundation, New York, N.Y., Hazen Foundation, New Haven, Conn., New York Times Foundation, N.Y., Rockefeller Foundation, New York, N.Y. and William Randolph Hearst Foundation, Los Angeles, Calif. (Eds.), Youth service. A guidebook

Conrad, D., \& Hedin, D. (1991). School-based community service: What we know from research and theory. [Electronic version]. Phi Delta Kappan, 72(10), 743-749.

Evans, B. and Shields, J. 1998. Reinventing the State: Public Administration 'Reform' in Canada. Halifax: Fernwood Publishing

Eyler, J., \& Giles, D. E. (1999). Where's the learning in service-learning?Jossey-Bass.

Flanagan, C. A. (2004). Volunteerism, leadership, political socialization, and civic engagement. In R. M. Lerner, \& L. Steinberg (Eds.), Handbook of adolescent psychology (2nd ed., pp. 721). Hoboken, NJ: John Wiley \& Sons, Inc.

Foster, M., and Meinhard, A., (2005). The diversity of revenue sources among voluntary organizations in Canada. Nonprofit Management and Leadership, 15(3), 43-60

Goodlad, J. (1984) A Place Called School. New York: McGraw-Hill.

Kahne, J., \& Westheimer, J. (1996). In the service of what? the politics of service learning. [Electronic version]. Phi Delta Kappan, 77(9), 592-599.

Maybach, C. W. (1996). Investigating urban community needs: Service learning from a social 
justice perspective. [Electronic version]. Education And Urban Society, 28(2), 224-236.

Melaville, A., Berg, A. C., \& Blank, M. J. (2006). Community-based learning: Engaging students for success and citizenship.

McLellan, J.A. \& Youniss, J. (2003). Two systems of youth services: determinants of voluntary and required youth community service. Journal of Youth and Adolescence, 32(1), 47-58.

Melchior, A. (1998). National evaluation of learn and serve America school and communitybased programs. Final report. U.S.; Massachusetts.

\section{ERIC Docs.pdf}

Meinhard, A. \& Foster, M. (1998). Community Service Programs in Toronto's Secondary Schools. Toronto: Centre for Voluntary Sector Studies Working Paper Series, \#10. WP10.pdf

Meinhard, A. \& Foster M. (2003). Differences in the response of women's voluntary organizations to shifts in Canadian public policy, Nonprofit and Voluntary Sector Quarterly, 32 (3), 366-396.

Meinhard, A., Foster, M., \& Wright, P. (2006). Rethinking school-based community service: The importance of a structured program. The Philanthropist, 20(1), 5-22.

Padanyi, P., Meinhard, A., \& Foster, M. (2003). A study of a required youth service program that lacks structure: Do students really benefit? Presented at the Annual Conference of the Association of Research on Nonprofit Organizations and Voluntary Action (ARNOVA), Denver, Colorado.

Pancer, S., Brown, S. D.,M., Henderson, A., \& Ellis-Hale, K. (2007). The Impact of High School Community Service Programs on Subsequent Volunteering and Civic Engagement. Toronto: Imagine Canada. ImagineCanada.ca/ mandatoryVolunteeringFeb07_2007.pdf

Putnam, R.D. (2000). Bowling alone: The collapse and revival of American community. Toronto: Simon \& Schuster.

Sanders, M. G. (2003). Community involvement in schools: From concept to practice. [Electronic version]. Education And Urban Society, 35(2), 161-180.

Scales, P. C., \& Roehlkepartain, E. C. (2004). Community service and service-learning in U.S. public schools, 2004: Findings from a national survey. A Research Report from the National Youth Leadership Council. 
Shumer, R. (1994). Community-based learning: Humanizing education. [Electronic version]. Journal of adolescence, 17(4), 357.

Shumer, R. (1997). Learning from qualitative research. In A. S. Waterman (Ed.), Servicelearning: Applications from the research (pp. 25-38). Mahwah, NJ: Lawrence Erlbaum Associates.

Shumer, R., \& Belbas, B. (1996). What we know about service learning. [Electronic version]. Education and Urban Society, 28(2), 208-223.

Stoneman, D. (2002). The role of youth programming in the development of civic engagement. [Electronic version]. Applied Developmental Science, 6(4), 221-226.

Sundeen, R. A., \& Raskoff, S. A. (1994). Volunteering among teenagers in the united states. Nonprofit and Voluntary Sector Quarterly, 23, 383-403.

Youniss, J., McLellan, J. A., \& Mazer, B. (2001). Voluntary service, peer group orientation, and civic engagement. [Electronic version]. Journal of Adolescent Research, 16(5) 
